many of these problems and that it may be applied to solve some of them under wide conditions. One might single out his work on the Kolmogorov equations and his work with Dr. D. G. Kendall (now professor of mathematical statistics at Cambridge) on ergodic theory and on 'pathological' Markov chains.

\section{Pure Mathematics in the University of Durham}

Following the appointment of Prof. G. E. H. Reuter to a professorship in mathematics in the Imperial College of Seience and Technology, two professorships have been established in pure mathematics in the University of Durham. Dr. T. J. Willmore and Dr. C. Hooley have been appointe $d$ to these chairs.

\section{Prof. T. J. Willmore}

Dr. Willmore was educated at Palmer's School, Grays, and King's College, London, where in 1939 he gained a B.Sc. degree with first-class honours in mathematics. He was appointed an assistant in the Mathematics Department at King's College, but the outbreak of the Second World War changed his plans and from 1939 until 1946 he was on the scientific staff of the Royal Air Force at Cardington. After the War, preferring a university career to the Scientific Civil Service, he resigned his appointment and in 1946 became a lecturer in mathematics at Durham. In 1954 he was appointed lecturer in the Department of Pure Mathematics at Liverpool, and became a senior lecturer in 1956 and a reader in 1962. Dr. Willmore's early research was on elasticity and relativity theory, but he soon became interested in differential geometry and most of his work has been in this field. He has published many papers on harmonic spaces, parallel distributions and derivations on manifolds, and has more recently become interested in global problems, particularly those related to curvature. $\mathrm{H}_{\theta}$ is the author of $A n$ Introduction to Differential Geometry, which is now a standard undergraduate and postgraduate text in Britain and the United States. He also collaborated with H. S. Ruse and A. G. Walker in the production of a monograph on harmonic spaces and with I. R. Porteous in an undergraduate text on topological geometry which is soon to be published. The training of mathematics teachers is a particular interest of Dr. Willmore's and he has for some time actively assisted the Institute of Education and the Extra-Mural Department in Liverpool, where he helped to organize and run courses designed to bring teachers up to date in modern mathematics. It is always a compliment to be appointed as a senior member of a university where one was formerly a junior, and Dr. Willmore's distinction as a geometer and a teacher, together with his energy and wide interests, will contribute much to his former university and its Mathematics Department. Dr. Willmore takes up his new appointment on October 1.

Dr. C. Hooley

Dr. Hooley was educated at Abbotsholme School, Derbyshire, and (after two years national service) at Corpus Christi College, Cambridge. He was a Fellow of the College from 1955 until 1958, and since then has been a lecturer in mathematics at the University of Bristol. Dr. Hooley's researches in the analytic theory of numbers have brought him an international reputation among experts in the field. The subject is one which has been deeply investigated during the past fifty years, and the frontier of the knowledge which is attainable by conventional methods is fairly well defined. But it is sometimes possible to make further advances by a combination of analytical and arithmetical reasoning, the latter being technically elementary but usually very difficult. In this way Dr. Hooley has succeeded in proving a number of results that had previously appeared to be out of reach. As an illustration, one may mention his proof (Math. Zeitschrift, 69, 259; 1958) that for 'almost all' those numbers that are representable as $x^{3}+y^{3}$, with positive integers $x, y$, there is only one such representation.

Medical Research Council : Appointment of Head of Division of Physiology and Pharmacology, National Institute for Medical Research

Prof. B. Delisle Burns has been appointed to the scientific staff of the Medical Research Council as head of the Division of Physiology and Pharmacology at the National Institute for Medical Research, in succession to Prof. W. S. Feldberg, who will be retiring from this post in November 1965. Prof. Burns, at present professor and chairman of the Department of Physiology, McGill University, Montreal, was a member of the Council's staff at the National Institute from 1946 until 1950. He has been particularly concerned with neurophysiological investigations of the brain, and it is intended that his work in this field should be continued when he takes up his appointment at Mill Hill next year.

\section{Computers, Technologists and their Applications}

IN a written answer in the House of Commons on June 24, the Minister of Technology, Mr. F. Cousins, gave the names of 17 research associations which actively encouraged the use of computers in their respective industries; of 18 research associations which had access to computers on their premises, at universities or at member firms; of 15 research associations using computers in their routine research (the names of some associations appear on all three lists). In another written answer on June 24, Mr. Cousins stated that of 4,064 non-industrial Civil Servants employed by his Department on June 1, $1965,1,400$ had university degrees or equivalent qualifications in scientific or technological subjects, and about another 1,400 had other scientific or technological qualifications. In a third written answer, Mr. Cousins stated that since the creation of his Department, besides the sponsored study by the Tavistock Institute of Human Relations of factors affecting the status of $\in$ ngineers, and work on behalf of the Committee on Manpower Resources for Science and Technology, action was in hand, in collaboration with other Departments, to promote the greater use of technological subjects in television and radio programmes, and to produce special booklets and films for wide distribution among young people.

\section{Oceanographic Research}

IN reply to questions regarding oceanographic research and the representation of the Ministry of Defence on the Natural Environment Research Council, in the House of Lords on June 22, the Minister of State for Education and Science, Lord Bowden, said that the Government was quite satisfied in this respect. The membership of the Council included Prof. M. J. Lighthill, Sir Edward Bullard, Prof. J. E. Harris and Dr. C. M. Yonge, all of whom had made important contributions to oceanography or related fields and had served on the National Oceanographic Council. The torms of reference of the Natural Environment Research Council were adequate for it to continue to advance the national effort in scientific oceanography, and this would be assisted by the fact that there would be one source of funds for basic oceanographic research. The Ministry of Defence would have an assessor on the Natural Environment Research Council, and would also be represented on the Council's Committee responsible for oceanography. The Minister was anxious to continue to co-operate, and the Royal Navy's representatives on the Committee were determined that their Service's interest should be pursued as strongly as when the Admiralty administered the National Institute of Oceanography. There must be close co-operation between the Navy and oceanographic research-on which the Navy spent $£ 590,000$ in 1964 . On priority of oceanographic research, Lord Bowden said that priorities for various 